\title{
The Devil's Trick. Impossible Editions in the Lists of Titles from the Regular Orders in Italy at the End of the Sixteenth Century
}

\author{
Roberto Rusconi
}

La plus grande malice du diable est de nous faire croire qu'il n'existe pas

CHARLES BAUDELAIRE

After the publication of an Index librorum prohibitorum by Pope Clement viII, in 1596, the Sacred Congregation of the Index of prohibited books requested the regular orders to submit lists of all the books they owned. ${ }^{1}$ Each item in those lists was supposed to include five main bibliographic elements: author, title, place of publication, publisher/printer, year. ${ }^{2}$ The surviving lists sent to the Congregation are mainly kept by the Biblioteca Apostolica Vaticana in Rome. ${ }^{3}$ They reveal many titles that cannot be presently connected to a surviving book. Some may indeed be lost books, as has been suggested by other contributors to this volume, and elsewhere. All of this information, has, however to be used with great care. This paper will analyze the morphology of misleading bibliographic items, explaining how mistakes came to be made in the compilation of the book lists. The examples are taken from the work of the RICI project, a comprehensive retrospective analysis of this survey by the Congregation of the Index at the end of the sixteenth century. ${ }^{4}$

1 See the recostruction of the procedure in Gigliola Fragnito, 'L'Indice clementino e le biblioteche degli Ordini religiosi', in Rosa Marisa Borraccini and Roberto Rusconi (eds.), Libri, biblioteche e cultura degli ordini regolari nell'Italia moderna attraverso la documentazione della Congregazione dell'Indice. Atti del Convegno Internazionale (Macerata 30 maggio 1 giugno 2006) (Vatican: Biblioteca Apostolica Vaticana, 2006), pp. 37-59. All online resources quoted in this article were last consulted on 30 June 2015 .

2 See the document published by Marc Dykmans, 'Les bibliothèques des religieux d'Italie en l'an 1600', Archivum Historiae Pontificiae, 24 (1986), pp. 385-404, here p. 392 (Vatican Library, collection Vatican Latin, hereafter: VL, 11296, f. 123r).

3 An analytic description of the manuscripts can be found in Marie-Madeleine Lebreton and Luigi Fiorani, Codices Vaticani Latini. Codices 11266-11326. Inventari di biblioteche religiose italiane alla fine del Cinquecento (Vatican: Biblioteca Apostolica Vaticana, 1985).

4 On the project Ricerca sull'Inchiesta della Congregazione dell'Indice (RICI), see Borraccini and Rusconi, Libri, biblioteche e cultura degli ordini regolari; Roberto Rusconi, 'Le biblioteche 
That request by the Congregation of the Index that those charged with making the inventories should record the exact bibliographic data of any individual volume in full, clearly responded to the priorities of inquisitorial censorship: the aim was to detect prohibited books. The enquiry sought to pinpoint the exact issue of each text owned by individual monks or in institutional collections. Inaccurate descriptions had to be avoided, because they were often misleading. It happened, however, that the items in the lists were often bibliographically incomplete. As a matter of fact, a truly remarkable number of the lists of the books owned by the regular orders were drafted omitting the requested data concerning the publisher/printer. Monks and friars lacked the appropriate bibliographical skills for such a task. In some cases the missing information seems to have been the result of a strategy of concealment. It was quite common not to mention the editors of an opera omnia or the author of introductions and dedicatory letters when this might have revealed disapproved authors, for instance either Erasmus ${ }^{5}$ or Melanchthon. ${ }^{6}$

The list of the titles of the books owned by a Franciscan conventual, master Felice da Avezzano, living in the convent of Tagliacozzo, in the Abruzzi, systematically omitted the indication of the printer. As a consequence, the item listed as: "Bibia sacra. Ven., 1538" might refer to any of three different editions printed in Venice in that same year. ${ }^{7}$ The item could have referred to a copy of the Latin Vulgata, ${ }^{8}$ or to the Italian translation by Santi Marmochino, ${ }^{9}$ or

degli ordini regolari in Italia alla fine del secolo XvI', Rivista di storia del cristianesimo, 1 (2004), pp. 189-199; Rosa Marisa Borraccini (ed.), Dalla "notitia librorum" degli inventari agli esemplari. Saggi di indagine su libri e biblioteche dai codici Vaticani latini 11266-11326 (Macerata: EUM, 2009); Rosa Marisa Borraccini, Giovanna Granata and Roberto Rusconi, 'A proposito dell'inchiesta della S. Congregazione dell'Indice dei libri proibiti alla fine del ' 500 ', Il capitale culturale, 6 (2013), pp. 13-45, available online: <http://riviste.unimc.it/index.php/cap-cult/ article/view/400/434>.

5 Mario Rosa, “'Dottore o seduttor deggio appellarte": note erasmiane', Rivista di storia e letteratura religiosa, 26 (1990), pp. 5-33; Silvana Seidel Menchi, 'Sette modi di censurare Erasmo', in Ugo Rozzo (ed.), La censura libraria nell'Europa del secolo XVI (Udine: Forum, 1997), pp. 177-207; Flavia Bruni, "Erano di molti libri proibiti". Frate Lorenzo Lucchesi e la censura libraria a Lucca alla fine del Cinquecento (Rome: Marianum, 2009).

6 Flavia Bruni, “'Typographi e quorum officinis diversorum haereticorum opera prodiere”: religious books printed in Basel in post-Tridentine Italy', De Gulden Passer (forthcoming).

7 VL 11291, f. 177 v.

8 Biblia. Breves in eadem annotationes, ex doctiss. interpretationibus, et Hebraeorum commentariis. Interpretatio propriorum nominum Hebraicorum (Venice: Bernardino Stagnino, 1538) (Edit16 CNCE 5785).

9 La Bibia nuovamente tradotta dalla hebraica verita in lingua thoscana per maestro Santi Marmochino fiorentino dell'Ordine de predicatori della provincia romana (Venice: haer. Lucantonio Giunta, 1538) (Edit16 CNCE 5762). 
indeed the forbidden translation by Antonio Brucioli. ${ }^{10}$ An incomplete item would easily raise suspicions, since translations of the Bible and biblical commentaries were at least suspect in the eyes of the inquisitors."

The requested lists were sent to the Congregation of the Index over a period of about five years, starting in 1597. They had been drawn up following various procedures. A particular list could be the copy of a previous inventory, which had been prepared in accordance with the legislation of a regular order (when that prescription was observed). ${ }^{12}$ A copy of a document could include (and often did) a remarkable number of misunderstandings of the original text. The range of mistakes included garbling the names of printers and authors who were not Italian and the sort of errors that indicate a weak command of the Latin language. Abbreviation marks were quite often misunderstood. Misspellings in the transcription from a previous list, especially due to misunderstanding of the handwriting, are easy to identify, for instance when this results (and many times it does) from the omission of a sign of abbreviation.

Alternatively, a single list could have been drawn up after a direct inspection of each individual volume, mostly based on the title page. This was the case for the personal lists of friars and monks, who sometimes wrote them in their own hand. It also happened, however, that a member of a regular Order delegated to undertake this task inspected the rooms of the convents, to make a list of the titles of the books 'used' (ad usum) by individual friars and monks. Other misleading procedures affected those lists, since it is not unusual to discover that, instead of taking the bibliographical data from the front page of a volume, the redactor reported the intitulation on the spine or on the edges (obviously without any indication either of the place and year of printing or of the name of the

10 La Biblia quale contiene i sacri libri del Vecchio Testamento tradotti da la hebraica verità in lingua toscana per Antonio Brucioli (Venice: Francesco Bindoni \& Mapheo Pasini, 1538) (Edit16 CNCE 5763). Cf. Jesús Martínez De Bujanda (ed.), Index des livres interdits, vol. x (Sherbrooke, Québec: Université, Centre d'Études de la Renaissance - Geneva: Droz, 1996), p. 99 .

11 Gigliola Fragnito, La Bibbia al rogo. La censura ecclesiastica e i volgarizzamenti della Scrittura (1471-1605) (Bologna: Il Mulino, 1997).

12 On the legislation of the regular orders concerning books and libraries, see Silvia Alessandrini Calisti, 'Norme e consuetudini degli Eremiti camaldolesi di Montecorona su libri e biblioteche'; Roberto Biondi, 'Libri, biblioteche e "studia" nella legislazione delle famiglie Francescane (secc. XVI-XVII)'; Giovanni Grosso, 'I Carmelitani e i libri: alcune note sulla legislazione', in Borraccini and Rusconi (eds.), Libri, biblioteche e cultura degli ordini regolari nell'Italia moderna, pp. 309-335, pp. 337-379, pp. 381-394 respectively. See also Monica Bocchetta, 'La legislazione dei Minori conventuali sugli studi e sulle biblioteche, secoli XVI-XVII', in Francesca Bartolacci and Roberto Lambertini (eds.), Presenze francescane nel camerinese (secoli XIII-XVII) (Ripatransone: Maroni, 2008), pp. 249-271. 
printer). In addition, a list could have been compiled by putting together a number of lists of the books owned by different individuals. This kind of procedure was relatively common for the convents without a formal library. ${ }^{13}$ The Capuchins ${ }^{14}$ and the Reformed Franciscans ${ }^{15}$ often elected to prepare a collective list on a provincial basis, since those regular Orders prohibited any kind of personal property by their members, including books.

It was not at all uncommon for the bibliographical elements to be translated into an inventorial Latin, thereby making it hard to be certain of the identification of a specific issue, especially when the same work circulated in Latin and in the vernacular. Some booklists apparently resulted from dictation. ${ }^{16}$ Mistakes also arose from the mis-identification of one or more bibliographic elements in the early printed editions, especially when they were

13 In some cases a preliminary statement makes this explicit: "Somma di libri che se ritrouino nel monasterio di S. Maria di Colle Maggio in L'Aquila" (VL 11286, f. 212r); "Lista delli libri delli padri et monastero di S. Biagio d'Vgubbio de' Celestini” (vL 11286, f. 251r). Many lists of this kind can be found in Samuele Megli and Francesco Salvestrini (eds.), Congregazione di Santa Maria di Vallombrosa dell'Ordine di san Benedetto (Vatican: Biblioteca Apostolica Vaticana, 2013), and Cécile Caby and Samuele Megli (eds.), Congregazione Camaldolese dell'Ordine di san Benedetto (Vatican: Biblioteca Apostolica Vaticana, 2014) (Libri e biblioteche degli Ordini religiosi in Italia alla fine del secolo XVI, 1-2).

14 Edition of some lists by Vincenzo Criscuolo, 'I cappuccini salernitano-lucani e la cultura', in Vincenzo Criscuolo (ed.), I Frati Minori Cappuccini in Basilicata e nel Salernitano fra '50o e '6oo (Rome: Istituto storico dei cappuccini, 1999), pp. 174-271; 'Formazione e cultura tra i Cappuccini della Provincia dell'Umbria tra Cinque e Seicento', in Vincenzo Criscuolo (ed.), I Cappuccini nell'Umbria del Cinquecento (1525-1619) (Rome: Istituto Storico dei Cappuccini, 2001), pp. 119-265; 'Il catalogo delle biblioteche dei conventi cappuccini della Provincia di Milano alla fine del Cinquecento', in Laurentianum, 44 (2003), pp. 391-516; 'La biblioteca dei cappuccini ad Arezzo alla fine del '500 (cod. Vat. lat. 11322)', Atti e memorie della Accademia Petrarca di Lettere, Arti e Scienze, n.s., 66 (2004), pp. 401-429; 'La circolazione dei libri e delle idee nella Provincia dei cappuccini di Cosenza tra Cinque e Seicento: la formazione culturale e il catalogo delle biblioteche', Laurentianum, 47 (2006), pp. 439-571. See also Costanzo Cargnoni, 'Libri e biblioteche dei cappuccini della Provincia di Siracusa alla fine del secolo XVI', in Collectanea Franciscana, 77 (2007), pp. 63-151.

15 Roberto Biondi, Le biblioteche dei Francescani Riformati in Italia alla fine del Cinquecento (PhD thesis, Università di Padova, 2005); Roberto Biondi, "Vi sono certo altri scritti d'oscurissima interpretatione". Gli inventari dei fratres strictioris Observantiae durante l'inchiesta della Congregazione dell'Indice', Franciscana, 12 (2010), pp. 215-334.

16 See the arguments by Angelo Turchini, 'Libri, territorio e società in Romagna alla fine del XVI secolo. A proposito delle biblioteche monastiche romagnole nell'inchiesta della Congregazione dell'Indice dei libri proibiti', in Lorenzo Baldacchini and Anna Manfron (eds.), Il libro in Romagna. Produzione, commercio e consumo dalla fine del secolo XV all'età contemporanea (Florence: Olschki, 1998), pp. 249-284, p. 251. 
lacking the title page. We can easily understand that, at the end of the sixteenth century, a friar or a monk might not easily be able to detect those elements in an old printed edition. It could indeed happen that, when transcribing the publication data, somebody did not realize that in a colophon the digits of a year had been divided into two lines, and for this reason the date in the list had recorded only the date on the first line. For example, the list of the titles for the use of the Franciscan conventual Biagio da Camorano, in the convent of Fermo (in the Marches), included the item: "Margarita Decreti seu Tabula Martiniana edita per fratrem Martinum Ord. Pred. Venet., per Peregrinum de Pascaleo, 1480 ". ${ }^{17}$ As a matter of fact, Pellegrino Pasquali printed that book in the year 1486, and in the colophon the digits had been divided into two lines (see ill. 14.1). ${ }^{18}$

Another example of the same kind was offered by the monastery of S. Sepolcro di Astino (near to Bergamo, in Lombardy), belonging to the monks of the Congregation of Vallombrosa. The item in the list: "Silius Italicus poeta. Mediolani, per Antonium Zarotum, 1480",19 is likely to correspond to the edition of the Punica, printed in Milan in the following year. ${ }^{20}$ In the colophon the year was written in a quite peculiar way: "M.CCCCLXXX.PRIMO./LECTOR. BENIVOLE". It is hardly surprising that somebody did not realize that 'primo', i.e. first, had to be added as 'one' to the sum of Roman digits. It was even more difficult to detect the year from a colophon similar to an epigram. This occurred with a text printed in Venice by Nicolas Jenson. ${ }^{21}$ In the list of the titles owned by the library of the monastery Badia of Ripoli, not far from Florence, the list gave the correct indication of author, title and year of the edition, but did not include the place of printing and the printer's name: "Georgius Trapezius, In traductione Eusebij Pamphyli De preparatione euangelica. 1470". 22

Considering all these possible occasions for confusion, is it really strange to find the year of publication for a printed edition reported as '1441' in some

17 VL 11280, f. 122v.

18 Martinus Polonus, Margarita decreti seu Tabula Martiniana (Venice: Peregrinus de Pasqualibus Bononiensis and Dominicus Bertochus, 2 Sept. 1486) (ISTC imoo3240oo).

19 VL 11288, f. 190v (cf. Megli and Salvestrini, Congregazione di Santa Maria di Vallombrosa, XXII.1, 457, p. 313).

20 Silius Italicus, Punica, ed. Petrus Justinus Philelphus (Milan: Antonius Zarotus, for Johannes de Legnano, [not before 7 Nov.] 1481) (ISTC iso0505000).

21 Eusebius Caesariensis, De evangelica praeparatione, tr. Georgius Trapezuntius. With additions by Antonio Cornazzano (Venice: Nicolaus Jenson, 1470) (ISTC ieoo1180oo).

22 VL 11288, f. $57 v$ (cf. Megli and Salvestrini, Congregazione di Santa Maria di Vallombrosa, III.1., 143, p. 156). 


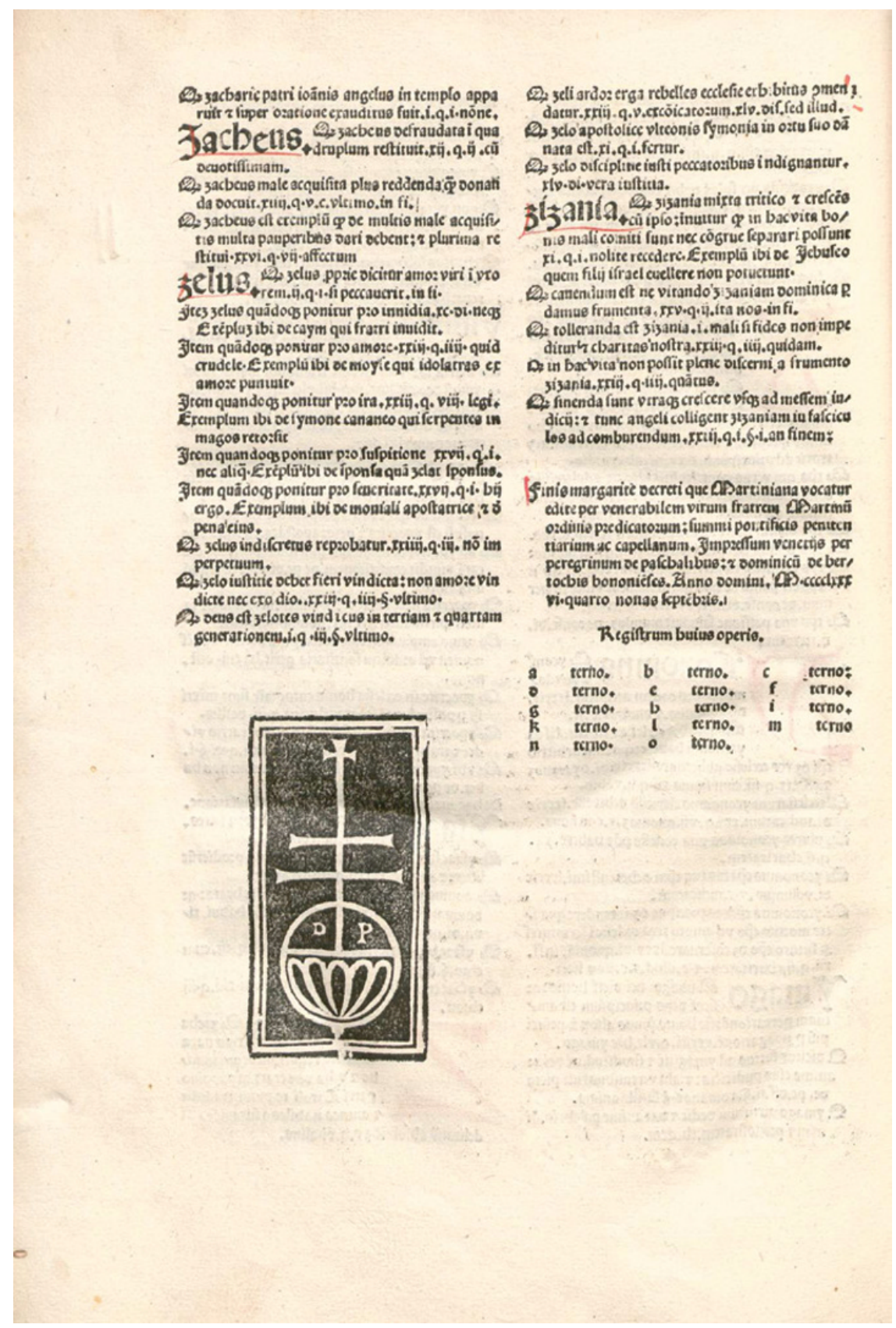

illustration 14.1 Martinus Polonus, Margarita decreti seu Tabula Martiniana (Venice: Peregrinus de Pasqualibus Bononiensis and Dominicus Bertochus,

2 Sept. 1486), f. $o_{4} v$

(C) BSB-Ink M-233 [2.Inc.c.a.1799] 
lists ${ }^{23}$ In a number of cases the place and the year had been taken from a letter of dedication, found in the first pages of a volume. A friar belonging to the Servites, Agostino Galli from Milan, wrote this item in his list: "Comentaria Themistij. Ven., 1480". ${ }^{24}$ As a matter of fact, Themistius Peripateticus' Paraphrasis in Aristotelem, had been printed in Venice by Johannes Hamman in the year $1500 .{ }^{25}$ However, in the first page, at the end of a letter by Ermolao Barbaro one could easily read: "Vale. Venetiis. M.CCCC.LXXX." A more common cause of confusion was the incorrect transcription of the title page, notably when expanding abbreviations and above all when changing the indication of the year of printing from Roman to Arabic numerals (not to mention that in many lists mistakes were also made in copying Arabic numerals).

Some mistakes resulted from peculiar printing practices, which gave rise to the indication of strange years. As a consequence, in a list of the books belonging to the monk Mauro da Badia Polesine, in the Camaldolese monastery in Murano (Venice), the year 1273 was assigned ${ }^{26}$ to an edition of the Venetiae by Germain Audebert, which in fact was printed in Venice by Aldo II Manuzio in the year 1583 (ill. 14.2). ${ }^{27}$ Mistakes in the use of Roman numerals on the editions were also possible. La filosofia morale del Doni was printed in Ferrara in the year 1590, but according to the Roman numerals on its title page, the year became 1610 (ill. 14.3). To get that result, all it took was to place an $\mathrm{X}$ after a $\mathrm{C}$, rather than before. ${ }^{28}$

Similar mistakes appeared quite frequently in the lists of the books owned by the regular Orders. It could also produce peculiar effects. The indication of the year could be even limited to three digits. "Vita beati Francisci s. Bonauenturae. Per Filippum Iuntam, 159" is an item recorded in the list of the books owned by the Reformed Franciscans in the convent of Poggio Nativo (near Rieti). ${ }^{29}$ There is no doubt that the corresponding edition was Bonaventura da Bagnorea's Legenda maior beati Francisci, printed in Florence

23 See, for instance, the records for the Summa Pisanella by Niccolò da Osimo and its Supplementum given as printed in the year 1441 in the RICI database: BIB 57579; 28152; 30767; 20097.

24 VL 11321, f. 69 r.

25 Cf. ISTC itoo1300oo and ISTC itoo131000.

26 VL 11287, f. 203r: "Germani Aduberti Aurelij Uen. ad serenissimum principem Nicolaum de Ponte. Venetijs, apud Aldum, 1273" (cf. Megli and Salvestrini, Congregazione di Santa Maria di Vallombrosa, XXvir.3, 8, p. 349).

27 Germain Audebert, Venetiae (Venice: Aldo Manuzio II, 1583) (Edit16 CnCE 3366).

28 Anton Francesco Doni, La filosofia morale tratta da molti antichi scrittori (Ferrara: Benedetto Mammarello, 1610 [i.e. 1590]) (Edit16 CNCE 17722).

29 VL 11286, f. $35^{\nu}$. 


\section{GER M A N I \\ A V D EBER T I A V R E L I I \\ VENETIAE \\ A D}

SERENISS - A C - SA PIENTISS. VENETIARVM . PRINCIPEM

NICOLAVM - DEPONTE E $T$

ILLVSTRISS.ATQ. PRVDENTISS. SENATORES. PATRICIOSQ. VENETOS

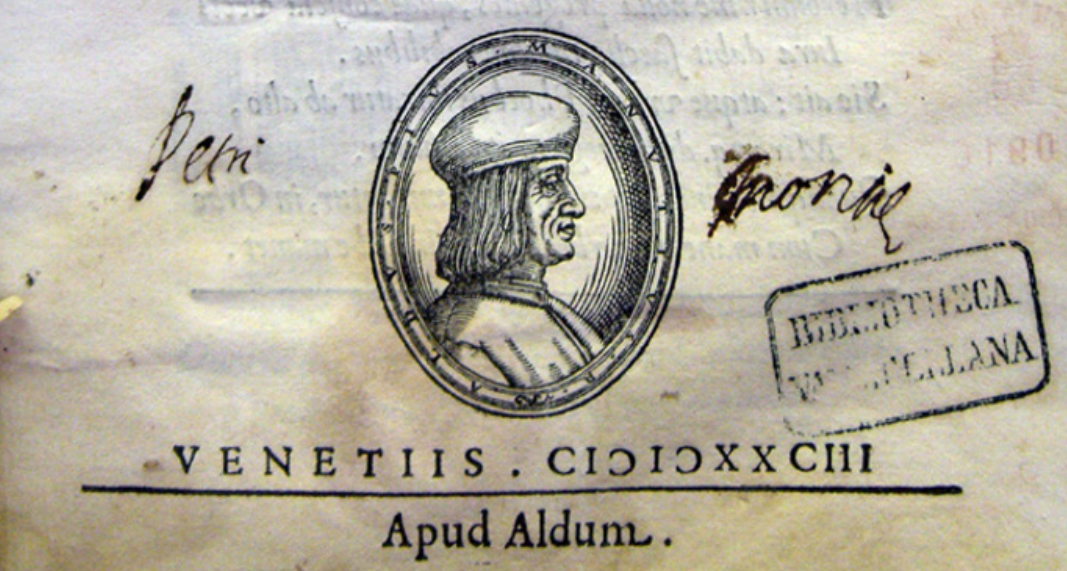

ILLUStration 14.2 Germain Audebert, Venetiae (Venice: Aldo Manuzio II, 1583), title page (c) Biblioteca Vallicelliana, Rome [S.Borr.H.II.168] 


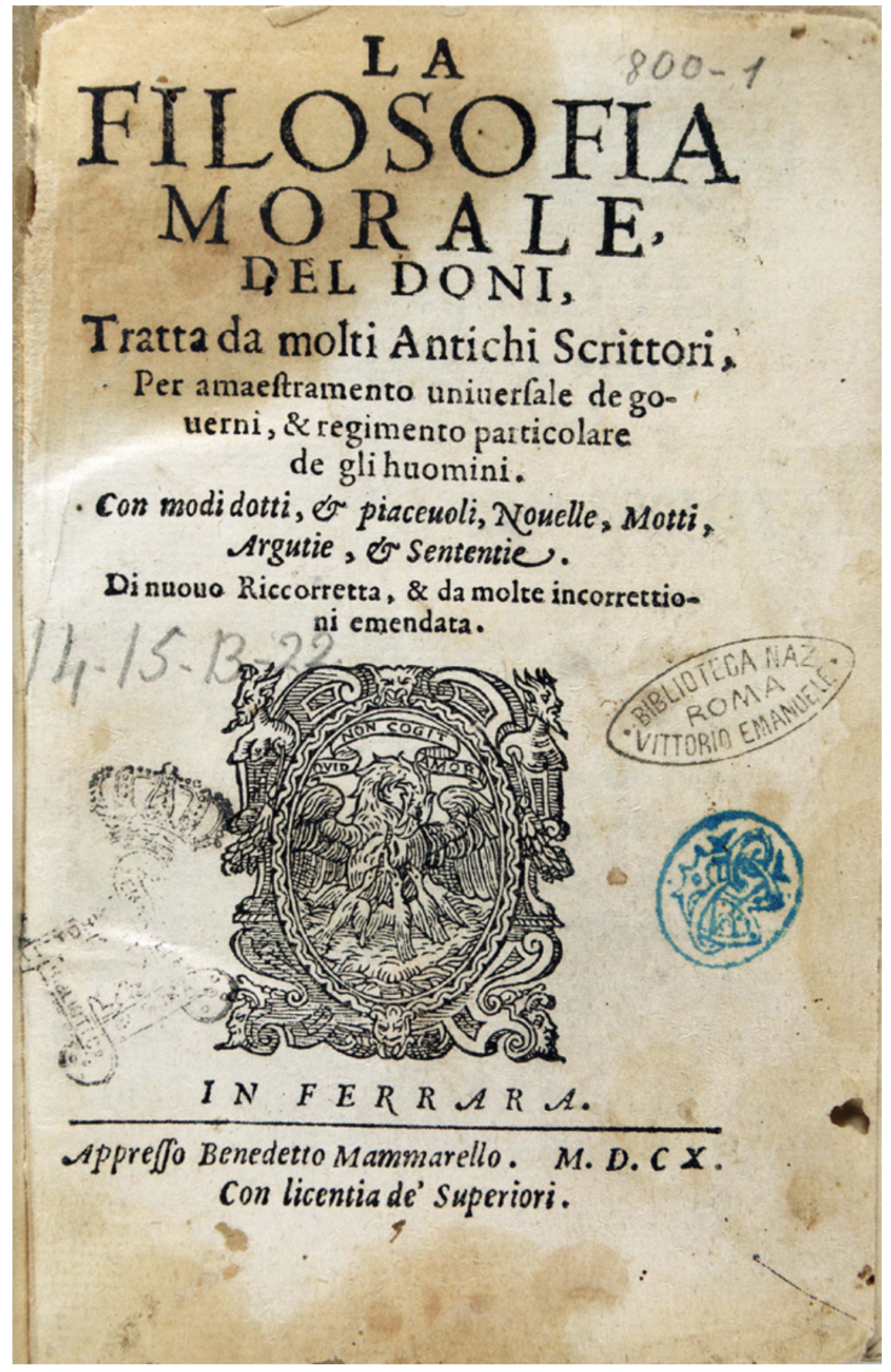

ILluStration 14.3 Anton Francesco Doni, La filosofia morale tratta da molti antichi scrittori (Ferrara: Benedetto Mammarello, 1610 [i.e. 159o]), title page

(C) Biblioteca Nazionale Centrale, Rome [12.27.D.2] 
by Filippo Giunta. ${ }^{30}$ In this case, a year written in Roman numerals (M.D.IX.) had been simply transliterated into Arabic numerals. The same type of erroneous practice could be really misleading in other cases. In the list of books belonging to the monks of the Benedictine monastery S. Pietro in Modena the item: "Institutiones vitae monasticae Laurentii Iustiniani. Brixiae, per Iacobum Britannicum, $1511^{\prime 31}$ suggests the existence of an unknown edition of the work, if one does not realize that the Roman numerals M.D.II. for 1502 in the printed book $^{32}$ had been literally transliterated into the corresponding Arabic numerals as 1.5.11. Even more frequently than the omission or misspelling of names and places, the erroneous indication of the year of printing of a certain issue gives rise to ambiguities that are often very difficult to resolve.

The activity over the years of editorial dynasties could also open the way to errors in the recording of printers' names. In the list of the books of the Benedictine monastery in Modena the item: "Institutiones Urbani Bolzanii. Venet., apud Aldum, $1560^{\prime 33}$ in fact referred to an edition printed by Paolo Manuzio. ${ }^{34}$ The bibliographic knowledge of the monk who wrote that list was obviously poor and he simply made reference to the front page, with the famous anchor, dolphin, and the name 'Aldus' (ill. 14.4).

Some practices were almost guaranteed to produce mistakes. In many cases the indication of the title of a volume was absolutely generic, like 'Logica', 'Philosophia', and so on. We can presume that such a generic title had indeed been taken from a direct inspection of each individual volume, but a hasty or careless one that looked no farther than the intitulation on the spine or on the edges (which obviously included no place and year of printing and no printer's name). A more interesting challenge is posed by the incomplete or incorrect identification of bibliographic elements in those instances - not at all uncommon - in which several distinct works had been bound together. The zealous religious who registered the bibliographic information found by checking the first and last pages of such a volume might thus invent a 'mixed' edition, formed by combining the bibliographic data from two different issues.

30 Bonaventura da Bagnorea, Aurea legenda maior beati Francisci (Florence: Filippo Giunta, 1509) (Edit16 CNCE 6873).

31 VL 11269, f. $278 r$.

32 Lorenzo Giustiniani, Institutiones vite monastice mortalibus universis ad bene beateque vivendum anhelantitus [!] quam utilissime (Brescia: Giacomo Britannico, 1502) (Edit16 CNCE 23230).

33 VL 11269, f. $278 r$.

34 Urbano Bolzanio, Grammaticae institutiones ad Graecam linguam, a mendis quamplurimis, quae paullatim ex impressorum irrepserant incuria, vindicatae (Venice: [Paolo Manuzio], 156o) (Edit16 CNCE 6787). 


\title{
VRBANI BOLZANII
}

\author{
B E L L V N E N S I S
}

GRA M M T I CAE IN T T TVTIONES

A D GRAECAM LINGVAM,

amendis quamplurimis, quæ paullatim

ex imprefforum irrepferant in-

curia, uindicatæ.
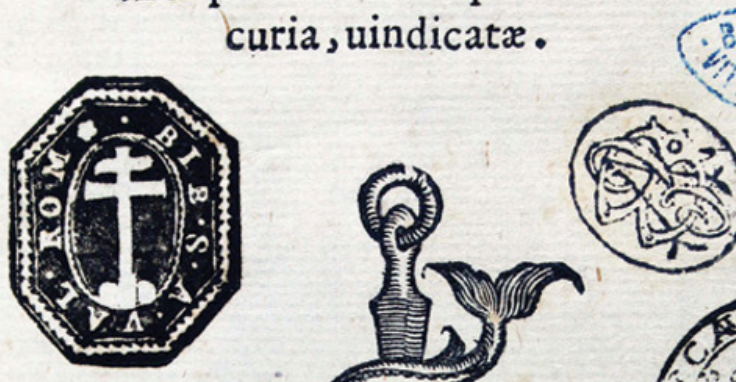

\section{1}

A L
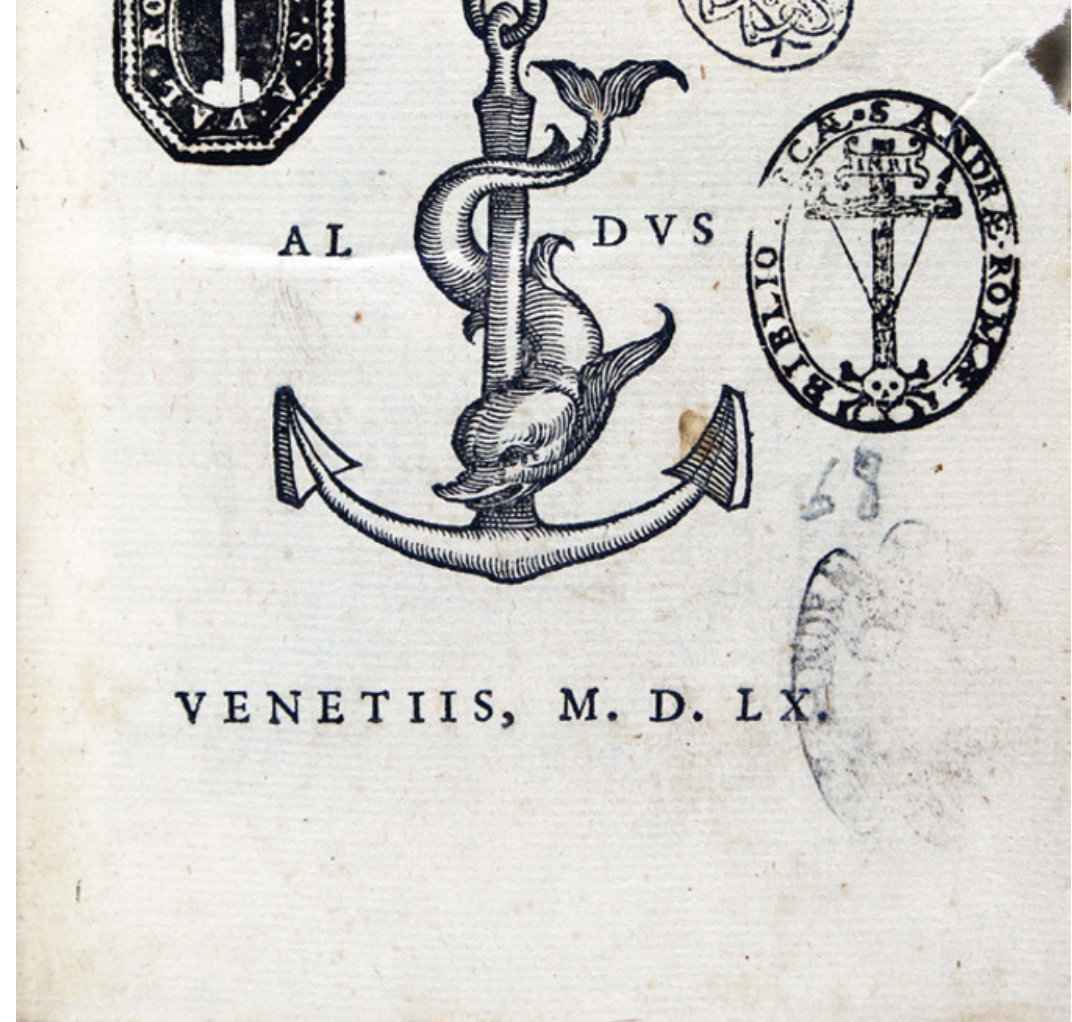

ILLUSTRATION 14.4 Urbano Bolzanio, Grammaticae institutiones ad Graecam linguam, a mendis quamplurimis, quae paullatim ex impressorum irrepserant incuria, vindicatae (Venice: [Paolo Manuzio], 1560), title page

(c) Biblioteca Nazionale Centrale, Rome [68.5.C.11] 
Since many of the volumes belonging to the Congregation of the Oratory in Rome are still preserved in the Biblioteca Vallicelliana at Rome and presumably correspond to the items enumerated in a list at the end of the sixteenth century, it is possible to compare listed item with surviving exemplars and confirm precisely this sort of conflation. ${ }^{35}$

On the contrary, a record including multiple works could prove actually to be referring to a single edition. This is the case, for instance, of the item described as:

Athinagorę Atheniensis philosophi christ. Apologia pro christianis ad Antoninum et Commodum. Eiusdem De resurrectione mortuorum. Vterque Grece et Latine, interpret. Appologię Corado Gesnero. Henr. Steph., 1557. Corradi Gesneri Annot. in Athenag. Apologiam. Henr. Steph. Epistula ad Petrum Nannium et annotationes in vtramque Athenagore orationem. ${ }^{36}$

The record carefully describes the edition of various works by Athenagoras Atheniensis translated into Latin by Conrad Gesner, whose name is on the title page, and printed in Geneva by Henri Estienne II in $1557 .{ }^{37}$

A record might also include large quotations of the title page. This happened for the description of the

Comentaria Io. Cocclei De actis et scriptis Mart. Lutheri, cum his uerbis in fronte: Multiplex pręparata et hic lectori vtilitas per rerum gestarum ex fide veritate narrationem, ut cognoscat quanta Luthero fuerit vis ingenij quantaque laborum tolerantia, quantus animi in affectib. impetus, quanta styli seuitia et qualia fuerint de eius doctrina papę, imperatorum, regum, conciliorum, episcoporum vniuersitatum Erasmi et id genus quo doctissimorum quorumlibet iudicia. ${ }^{38}$

35 Vatican, Archivio della Congregazione per la Dottrina della Fede (hereafter: ACDF), Index, XXII, ff. 236-280. Elisabetta Caldelli, Tra le carte: all'interno della lista degli Oratoriani (Vatican: Biblioteca Apostolica Vaticana, forthcoming) (Libri e biblioteche degli Ordini religiosi in Italia alla fine del secolo XVI, 3).

36 Vatican, ACDF, Index, XXII, ff. 240v-241r.

37 Athenagoras Atheniensis, Apologia pro christianis ad imperatores Antoninum \& Commodum. De resurrectione mortuorum, uterque Grcese et Latine ([Geneva]: Henri Estienne II, 1557) (USTC 450451).

38 Vatican, ACDF, Index, XXII, ff. $245^{v-246 r}$. 
Even without any information about printer, date or place of printing, the identification of this item with a copy of the edition of the Commentaria de actis et scriptis Martini Lutheri by Johann Cochlaeus, printed in Mainz by Franz Behem in 1549, is made certain by the accurate transcription of the title page included in the description above. ${ }^{39}$

The identification of copies of different editions bound together with no indication of printing whatsoever is only made possible by the discovery of the actual volume the record referred to. One excellent example is the series of items listed below:

Homerocentra. Una cum interpretatione Latina et imagine obscena. Nonni Panoplitani. In Euangelium Ioannis in Gręc. .

Item Io. Chrisostomi Missa Gręcolatina, Erasmo interprete. Paris., apud Christianum Vuecchelum, 1537.

Item eiusdem Chrisostomi De fato et prouidentia Dei. Basileę, apud Io. Frobenium, 1526 .

Eiusdem In epistulam ad Philipp. homilie duę, Erasmo interprete .

Item Antonij Tilesij De coronarum generibus.

Item Eiusdem De celeritate etc.

Item De regionibus nou. Rom.

Dialogj Osci et Vollsci etc.

Item Adriani Turnebij Epitaloemium Francisci Valesij. Huld \{erici Huteni $\}$ arte uersificatoria. ${ }^{40}$

These are actually short and incomplete descriptions of several editions bound together in a single volume of the Biblioteca Vallicelliana in Rome. ${ }^{41}$

Early modern booklists, like the ones investigated by the RICI project, can be a source of knowledge about lost books, notably for editions that were not intended to form part of a library of any kind, for example liturgical books, usually stored in the sacristy of a church. Books intended for everyday use,

39 Johannes Cochlaeus, Commentaria de actis et scriptis Martini Lutheri (Mainz: Franz Behem, 1549) (USTC 663508).

40 Vatican, ACDF, Index, XXII, ff. $25^{8 v-259 r . ~}$

41 Rome, Biblioteca Vallicelliana, Sala Borromini, I.IV.215. For details on the editions see ELE 6559 in the RICI database, records $371-381$ (forthcoming). For other similar instances amongst the books belonged to the Servite convent of S. Piero Piccolo in Arezzo, see Flavia Bruni, 'The Book Inventories of Servite Authors and the Survey of the Roman Congregation of the Index in Counter-Reformation Italy', in Malcom Walsby and Natasha Constantinidou (eds.), Documenting the Early Modern Book World. Inventories and Catalogues in Manuscript and Print (Leiden: Brill, 2013), pp. 207-230. 
such as devotional works and pastoral manuals, were used until they were completely worn out, discarded or replaced, despite the provisions of the legislation of the regular Orders (for instance, the book used by deceased friars had to be either returned to the library of their own convent or assigned to other friars). An excellent example is the Confessionario of the Dominican friar Girolamo da Palermo, a small manual for confession, whose survival rate appears significantly low if compared to the number of copies listed in the RICI database, as carefully analysed by Rosa Marisa Borraccini in this volume. However, we must bear in mind that though the presence of the same bibliographical record in several lists, related to different Orders in different places, often does imply the existence of a new, unknown edition, it does not exclude the possibility that different individuals could have made the same mistake. It is necessary to conclude with another injunction to caution: the Devil is always at work. 